\title{
Improving High Order Thinking Skills (HOTS) Through the Trikaya Parisudha Learning Model
}

\author{
I Gede Astawan ${ }^{*}$, Ni Made Dyan Anggreni², Setyo Eko Atmojo ${ }^{3}$, A. Ardiansyah ${ }^{4}$ \\ 1,2 Universitas Pendidikan Ganesha, Singaraja, Indonesia \\ 3Universitas PGRI Yogyakarta, Yogyakarta, Indonesia \\ ${ }^{4}$ Universitas Islam Negeri Datokarama Palu, Palu, Indonesia
}

\section{ART ICLE INFO}

\section{Article history:}

Received August 22, 2021

Revised August 29, 2021

Accepted November 06, 2021

Available online November 25, 2021

Kata Kunci:

Model Pembelajaran, Trikaya

Parisudha, Higher Order Thinking

Skills

Keywords:

Learning Model, Trikaya Parisudha, Higher Order Thinking Skills

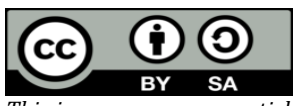

This is an open access article under the $C C$ BY-SA license.

Copyright (c) 2021 by Author. Published by Universitas Pendidikan Ganesha.

\begin{abstract}
A B S T R A K
Permasalahan di bidang pendidikan selalu menjadi isu penting di setiap negara di dunia, termasuk Indonesia. Hampir semua siswa Indonesia ternyata hanya menguasai pelajaran sampai level 3 saja. Sementara, banyak siswa negara maju dan berkembang lainnya menguasai pelajaran sampai level 4, 5, bahkan 6. Tujuan penelitian ini yaitu menganalisis perbedaan High Order Thinking Skills (HOTS) antara kelompok yang diberikan Model Pembelajaran Trikaya Parisudha (MPTP) dan yang diberikan Model Pembelajaran Konvensional (MPK). Penelitian ini merupakan kuasi eksperimen dengan pretest posttest control group design. Populasi penelian adalah mahasiswa PGSD berjumlah 7 kelas. Dari 7 kelas tersebut dipilih 4 kelas dengan cara cluster random sampling. Dua kelas sebagai kelompok eksperimen dan dua kelas lainnya sebagai kelompok kontrol. Kelompok eksperimen dibelajarkan dengan MPTP. Sementara itu, kelompok kontrol dibelajarkan dengan MPK. Metode yang digunakan untuk mengumpulkan data yaitu observasi, wawancara, dan kuesioner. Instrument yang digunakan untuk mengumpulkan data yaitu lembar observasi. Teknik analisis data yang digunakan adalah statistik deskriptif dan statistik inferensial. Hasil penelitian menunjukkan bahwa terdapat perbedaan HOTS mahasiswa, antara kelompok yang diberikan MPTP dan kelompok yang diberikan MPK. Terdapat perbedaan Critical Thinking Skills antara kelompok yang diberikan MPTP dan kelompok yang diberikan MPK. Terdapat perbedaan Creative Thinking Skills antara kelompok yang MPTP dan kelompok yang diberikan MPK. Dapat disimpulkan bahwa Model Pembelajaran Trikaya Parisudha dapat meningkatkan berpikir tingkat tinggi pada mahasiswa.
\end{abstract}

A B S T R A C T

Problems in education have always been an essential issue in every country, including Indonesia. Almost all Indonesian students only master the lessons up to level 3 only. Meanwhile, many students from developed and developing countries have mastered lessons up to 4, 5, and even 6. The purpose of this study is to analyze the differences in High Order Thinking Skills (HOTS) between the groups given the Trikaya Parisudha Learning Model (MPTP) and those given the Conventional Learning Model. (MPK). This research is a quasi-experimental with pretest-posttest control group design. The research population is PGSD students in 7 classes. From the 7 classes, 4 classes were selected using random cluster sampling two classes as the experimental group and the other two classes as the control group. MPTP taught the experimental group. Meanwhile, the control group was taught with MPK. The methods used to collect data are observation, interviews, and questionnaires. The instrument used to collect data is the observation sheet. The data analysis technique used is descriptive statistics and inferential statistics. The results showed differences in student HOTS between the group given MPTP and the group given MPK. There is a difference in Critical Thinking Skills between the group given MPTP and the group given MPK. There are differences in Creative Thinking Skills between the group receiving MPTP and the group receiving MPK. It can be concluded that the Trikaya Parisudha Learning Model can improve students' higher order thinking.

\section{INTRODUCTION}

Problems in education have always been an essential issue in every country, including Indonesia. In Indonesia itself, development in education continues to be pursued towards the formation of quality Human Resources (HR). Quality human resources are believed to bring the Indonesian nation out of ignorance towards a more advanced nation (Khayati et al., 2020; Winataputra, 2016; Yamin \& Syahrir, 2020). The government has made various efforts to create quality human resources (Fitriani, 2019; Jessica et al., 2017; Suwartini, 2017). One of them is developing a learning model that will later be applied more broadly by education practitioners in the classroom (Dewi, Kusmariyatni, et al., 2016; Kaban et al., 2021; Kristiana \& Radia, 2021; Leonard \& Nwanekezi, 2018). The various government efforts above have not 
improved the quality of education significantly. The education development index for all (education for all), according to UNESCO in the 2011 EFA Global Monitoring Report, reports that Indonesia ranks 67 out of 127 countries (Yuliati \& Lestari, 2019). The Program for International Student Assessment (PISA) in 2018 placed Indonesia in rank 70 out of 78 countries (Nugrahanto \& Zuchdi, 2019; Septya Nugrahanto \& Zuchdi, 2019). The assessment criteria used include students' cognitive abilities and reading, mathematics, and science skills. Almost all Indonesian students only master the lessons up to level 3 only. Meanwhile, many students from other developed and developing countries have mastered lessons up to 4, 5, and even 6 . Mastery at level 1, level 2, and level 3 show that higher-order thinking skills are pretty low (Afrita \& Darussyamsu, 2020; Ndiung \& Jediut, 2020; Yuliati, 2013). This fact confirms that education needs serious attention for education practitioners.

The need for a learning model by exploring Balinese local wisdom is necessary (Dewi, Tastra, et al., 2016; Wijaya et al., 2019). The local wisdom-based learning model needed is a model that can optimize HOTS. Until now, teachers in Bali have not used much local culture-based learning. It is evidenced by the results of research, which conclude that learning in elementary schools in Bali refers more to the Western approach (Budiwibowo, 2016; Dwija Putri et al., 2017). This condition occurs among Balinese elementary school children. Thus, children do not become alienated from their own culture. It is in line with the thoughts of educational figures interested in using local culture in the world of education (Bekagema et al., 2016; Putrihapsari \& Dimyati, 2021). In schools, science learning should balance Western science (modern science) and original science (traditional science) using a cross-cultural approach to keep local wisdom from eroding. The subculture of modern science taught in schools is in harmony with the subculture of students' daily lives, so learning science tends to strengthen students' views (Anif et al., 2020; Lai et al., 2019; Rusli et al., 2020; Setiawan et al., 2017). If they are different, let alone contradictory, then science learning tends to destroy or separate students from their culture (Andriani et al., 2017; Havizul, 2020; Widodo, 2020). It has a negative connotation because it involves cultural imperialism, which students usually fight by paying less attention to lessons.

One of the main goals of science education in society should be comparing traditional views and scientific views, how they think, and clarifying the similarities and differences between the two (Clarisa et al., 2020; Jampel et al., 2018; Subali et al., 2019). Integrating native science with science lessons in schools can improve student achievement (Hurriyah, 2017; Indriyani et al., 2017; Tompodung et al., 2018). If students' traditional beliefs or views about the universe are not incorporated into the science learning process, the conflicts within students will continue to be carried away so that their understanding of scientific concepts becomes less meaningful. Departing from these problems, especially those related to the low HOTS, it becomes urgent to find a solution immediately. In this case, the solution offered is related to the suitable learning model for increasing HOTS (Harta et al., 2020; Ichsan et al., 2019). It takes a learning model suitable for use by the 2013 Curriculum in synergy with the development of potential regional advantages. In this research, a learning model based on local wisdom trikaya Parisudha is applied, allowing students to learn aspects of learning according to their cultural procedures. Tri Kaya Parisudha is one of the ethical teachings in Hinduism (Ayu et al., 2020; Selamet, 2017; Widiasih, 2019). Tri Kaya Parisudha is a guide in life. Tri Kaya Parisudha consists of three parts, namely Kayika Parisudha, which is good action; Wacika Parisudha, which is a kind word; Manacika Parisudha, namely good thoughts, thoughts from good thoughts will lead to self-purify (Priantini, 2020; Suryani et al., 2019; Ayu Veronika, 2019). Tri Kaya Parisudha, as part of ethical teachings in Hinduism, will provide guidance and a path to peace and harmony in life in this world and the hereafter (Ayu et al., 2020; Priantini, 2020).

Various studies support both theoretical and empirical studies also show success in implementing culture-based learning. Local science is strengthened by scientific scientists and scientific science in which learning becomes more meaningful because it gets a touch of local science. The findings of previous studies also stated that Tri Kaya Parisudha could improve students' character (Priantini, 2020; A. Veronika, 2019). The findings of previous studies also stated that tri kaya parisudha could improve student learning outcomes (Dewi et al., 2014; Somawati \& Made, 2019). There is no study of the Tri Kaya Parisudha learning model yet. This study aims to analyze the differences in High Order Thinking Skills (HOTS) between groups given the Trikaya Parisudha Learning Model (MPTP) and those given the Conventional Learning Model (MPK). It is hoped that the Trikaya Parisudha (MPTP) learning model can improve students' HOTS abilities.

\section{METHOD}

This research is a quasi-experimental study using a pretest-posttest control group design. The population of this research is PGSD students, totalling 7 classes. From the 7 classes, 4 classes were chosen randomly-two classes as the experimental group and the other two classes as the control group. The experimental group was treated with the Tri Kaya Parisudha learning model. Meanwhile, the control group 
was taught as usual using the conventional model, in which students did a paper presentation. The data collected in this study include: 1) tests and 2 collected critical thinking skills) observation sheets collected creative thinking skills. The methods used to collect data are observation, interviews, and questionnaires. The instrument used to collect data is the observation sheet. The data analysis technique used is descriptive statistics and inferential statistics. Descriptive analysis is used to describe the average value and standard deviation. Inferential statistical analysis was used to test the hypothesis using one-way MANOVA.

\section{RESULT AND DISCUSSION}

\section{Result}

The general description of the research results revealed consists of the distribution of the average score (Mean) and standard deviation (SD) based on the learning model (MPTP and MPK) given to each treatment cell. The average value of critical thinking skills between learning groups $(n=26)$ was $M=78.23$, $\mathrm{SD}=11.04$ for the MPTP group and $\mathrm{M}=66.58, \mathrm{SD}=9.99$ for the MPK group. These results indicate that MPTP descriptively is relatively better as a learning facility for students to improve students' critical thinking skills. In addition, it was also revealed that the average value of creative thinking skills between the learning groups $(n=26)$ was $M=77.58, S D=12.45$ for the MPTP group and $M=67.58, S D=10.78$ for the MPK group. These results indicate that descriptively MPTP is relatively better as a learning facility for students in order to improve students' creative thinking skills. The results of the multivariate test analysis showed three findings: the statistical values of Pillai's Trace, Wilk's Lambda, Hotelling's Trace, and Roy's Largest Root, with $\mathrm{F}=8.830$ and a significance value of 0.001 each. The significance number is smaller than 0.05. It means that the null hypothesis (H0), which states "there is no effect of the learning model on critical thinking skills and creative thinking skills, together", is rejected. In other words, the alternative hypothesis (H1), which states "there is an effect of the learning model on critical thinking skills and creative thinking skills, together", is accepted. So, learning models have different impacts simultaneously on critical thinking skills and creative thinking skills.

Second, based on the source of the influence of the learning model variable (MP) on the dependent variable KBKs, the statistical value of $F=8.830$ with a significant number of 0.0001 was obtained. This significance figure is smaller than 0.05. Thus the null hypothesis (Ho), which states that "there is no difference in the average score of critical thinking skills between the MPTP group and the MPK group", is rejected. In other words, the alternative hypothesis (H1), which states "there is a difference in the average score of critical thinking skills between the MPTP group and the MPK group", is accepted. So, there is a significant effect $(\mathrm{p}<0.05)$ on the variables of learning models on the critical thinking skills variable. Third, based on the source of the influence of the learning model variable (MP) on the dependent variable KBKf, the statistical value of $F=9.073$ with a significant number of 0.004 was obtained. This significance figure is smaller than 0.05. Thus the null hypothesis (H0), which states that "there is no difference in the average score of creative thinking skills between the MPTP group and the MPK group", is rejected. In other words, the alternative hypothesis (H1), which states that "there is a difference in the average score of creative thinking skills between the MPTP group and the MPK group", is accepted. So, the dependent variable of creative thinking skills is significantly $(\mathrm{p}<0.05)$ influenced by the learning model used. The findings above show a significant difference in critical thinking skills between the group of students who study with MPTP and the group of students who study with MPK. Students' critical thinking skills in the MPTP model group are higher than those in the MPK group. In other words, the MPTP learning model is superior to MPK in achieving KBKs. However, descriptively, the KBKs level of these students has not reached the maximum standard of success (still in the high category).

\section{Discussion}

Tri Kaya Parisudha learning is a constructivist understanding that states that students build their minds. Constructivism also states that students already have prior knowledge from daily experience and previous education levels (Nurhidayati, 2017; Prayito, 2011). Tri Kaya Parisudha learning in the classroom begins by providing opportunities for students and or providing contextual problems that are close to the environment around students. The initial questions presented to students are contextual, namely, actual questions around their environment and relevant to the material that students are expected to master (Gitriani et al., 2018; Mawardi et al., 2019; Pasaribu \& Saparini, 2017). Questions, statements, and illustrations presented at the beginning of the lesson are learning stimuli. When students face problems related to their lives, there will be a sense of responsibility to solve these problems so that they will be aware of exploring relevant information to solve the problems at hand (Balan et al., 2019; Century et al., 2020; Mulyani, 2020). The Tri Kaya Parisudha learning model provides opportunities and for students to build their knowledge and at the same time utilize their knowledge to solve contextual problems that exist 
around their environment (Artawan \& Ardiawan, 2018; Somawati \& Made, 2019). It makes learning meaningful because students can remember, understand, and apply their knowledge, perform, synthesize, and evaluate everything they have learned. This study also shows that MPTP is better than MPK for KBKf management. The KBKf achievement of students in the MPTP group was higher than that in the MPK group. In other words, that MPTP is superior to MPK in student KBKf education. Descriptively, the KBKf of the MPK group students was high. A good understanding can support critical, creative thinking, problem-solving skills, and decision making (Ayu et al., 2020; Selamet, 2017; Ayu Veronika, 2019). So, learning concept understanding is also learning for thinking skills, and learning thinking skills can be referred to as learning to improve higher thinking skills (Anisah \& Lastuti, 2018; Fayakun \& Joko, 2015; Kuantum et al., 2018).

MPTP is designed as learning thinking skills. The deep understanding that is achieved from the interaction between thinking and material in the Student Worksheet (LKM) and the exercises carried out by students will realize students' abilities in application, analysis, synthesis, and evaluation standards. That is, there is a transfer of understanding in solving real problems. MPTP, at the beginning of learning begins by growing students' interest and motivation in learning by linking content and context, providing benefits for students. After learning motivation grows, students can experience learning activities directly through LKM, which contains contextual problems (Buchori, 2019; Hernawati, 2016; Wulandari, 2016). The opportunity to collaborate in groups and in-depth discussions strengthen the concepts they already have, and every effort made by students is celebrated, according to the principle that if it is worth learning, it is also worth celebrating (Dewi et al., 2018; Putra \& Sujana, 2020).

Based on this explanation, it appears that MPTP tends to be superior to MPK in achieving students' creative thinking skills. This study also shows that variations in learning models affect the achievement of critical thinking skills and creative thinking skills (Dewi, Kusmariyatni, et al., 2016; Lian et al., 2020; Purwandari \& Wahyuningtyas, 2017). Tri Kaya Parisudha learning model is based on constructivism learning theory. Constructivism views that learners already know before they learn in the classroom (Duane \& Satre, 2014; Suwannaphisit et al., 2021; Yustina \& Kapsin, 2017). Thus, learning must depart from the initial knowledge that students already have (Arsa et al., 2019; Hamidah \& Yanuarmawan, 2018). In comparison, the conventional learning model is based on the learning theory of behaviourism. Behaviourism views the learner as a blank sheet of paper. Thus, learning is intended to fill as much knowledge as possible into the student's head. In increasing the effectiveness of MPTP, there are two options. First, if the contextual problem strategy uses an LKM, the LKM used must be understood by students. The problems presented in the MFI must be genuinely contextual. Second, during discussions, lecturers should become creative moderators and mediators to maximize the discussion. All students are invited to be responsible for the success of learning. Students or groups who can achieve satisfactory results should be celebrated.

\section{CONCLUSION}

HOTS students who are given MPTP are better than those given MPK. The Critical Thinking Skills of students who were given MPTP were better than those given by MPK. Creative Thinking Skills students given MPTP are better than those given MPK. For this reason, educators are advised to apply the Tri Kaya Parisudha learning model to improve students' Higher Order Thinking Skills (HOTS).

\section{REFERENCES}

Afrita, M., \& Darussyamsu, R. (2020). Validitas Instrumen Tes Berpikir Tingkat Tinggi (HOTS) pada Materi Sistem Respirasi di Kelas XI SMA. Jurnal Mangifera Edu, 4(2). https://doi.org/10.31943/mangiferaedu.v4i2.83.

Andriani, L. L., Suarjana, I. M., \& Lestari, L. P. S. (2017). Pengaruh Model Pembelajaran Think Pair Share Berbasis Budaya Masyarakat Lokal Terhadap Hasil Belajar Pkn Siswa Universitas Pendidikan Ganesha. Mimbar PGSD, 021(3). https://doi.org/10.23887/jjpgsd.v5i2.10624.

Anif, S., Sutopo, A., \& Prayitno, H. J. (2020). Lesson study validation: Model for social and natural sciences teacher development in the implementation of national curriculum in Muhammadiyah schools, Indonesia. Universal Journal of Educational Research, 8(1), 253-259. https://doi.org/10.13189/ujer.2020.080132.

Anisah, \& Lastuti, S. (2018). Pengembangan Bahan Ajar berbasis HOTS untuk Meningkatkan Kemampuan Pemecahan Masalah Matematis Mahasiswa. Kreano: Jurnal Matematika Kreatif-Inovatif, 9(2), 191197. https://doi.org/10.15294/kreano.v9i2.16341.

Arsa, D., Atmazaki, A., \& Juita, N. (2019). Literasi Awal pada Anak Usia Dini Suku Anak Dalam Dharmasraya. Jurnal Obsesi: Jurnal Pendidikan Anak Usia Dini, 3(1), 127. 
https://doi.org/10.31004/obsesi.v3i1.159.

Artawan, K. N., \& Ardiawan, I. K. N. (2018). Pembelajaran quantum Teaching berbasis Tri Kaya Parisudha. Edudikara: Jurnal Pendidikan Dan Pembelajaran, 3(2), 201-212. https://doi.org/10.32585/edudikara.v3i2.100.

Ayu, D., Manu, M., \& Priantini, O. (2020). The Development Of Teaching Video Media Based On Tri Kaya Parisudha In Educational Psychology Courses. Journal of Education Technology, 4, 448-455. https: //doi.org/10.23887/jet.v4i4.29608.

Balan, L., Yuen, T., \& Mehrtash, M. (2019). Problem-Based Learning Strategy for CAD Software Using FreeChoice and Open-Ended Group Projects. Procedia Manufacturing, 32, 339-347. https://doi.org/10.1016/j.promfg.2019.02.223.

Bekagema, M. D., Mahadewi, L. P. P., \& Tastra, I. D. K. (2016). Pengembangan Video Pembelajaran Budaya Masyarakat Hindu Bali Kelas IV SDN 3 Banjar Tegal. Jurnal Edutech Undiksha, 4(3). https://doi.org/10.23887/jeu.v4i3.8561.

Buchori, A. (2019). Pengembangan multimedia interaktif dengan pendekatan kontekstual untuk meningkatkan pemecahan masalah kemampuan matematika. Jurnal Inovasi Teknologi Pendidikan, 6(1), 104-115. https://doi.org/10.21831/jitp.v6i1.20094.

Budiwibowo, S. (2016). Hubungan Minat Belajar Siswa Dengan Hasil Belajar Ips Di Smp Negeri 14 Kota Madiun. Gulawentah:Jurnal Studi Sosial, 1(1), 60. https://doi.org/10.25273/gulawentah.v1i1.66.

Century, J., Ferris, K. A., \& Zuo, H. (2020). Finding time for computer science in the elementary school day: a quasi-experimental study of a transdisciplinary problem-based learning approach. International Journal of STEM Education, 7(1). https://doi.org/10.1186/s40594-020-00218-3.

Clarisa, G., Danawan, A., Muslim, \& Wijaya, A. F. C. (2020). Penerapan Flipped Classroom dalam Konteks ESD untuk Meningkatkan Kemampuan Kognitif dan Membangun Sustainability Awareness Siswa. Journal of Natural Science and Integration, 3(1), 13-25. https://doi.org/10.24014/jnsi.v3i1.8953.

Dewi, Kusmariyatni, \& Margunayasa. (2016). Pengaruh Model Pembelajaran Learning Cycle 5E Terhadap Hasil Belajar IPA Siswa Kelas V SD. Mimbar PGSD Undiksha, 4(1). https: //doi.org/10.23887/jjpgsd.v4i1.6658.

Dewi, N. K. C., Sedanayasa, G., \& Sulastri, M. (2014). Pengaruh Moidel Pembelajaran Numbered Head Together Berlandasakan Tri Kaya Parisudha Terhadap Hasil Belajar IPA Siswa Kelas V. Mimbar Pgsd Universitas Pendidikan Ganesha, 2(1). https://doi.org/10.23887/jjpgsd.v2i1.4144.

Dewi, N. K. R., Tastra, I. D. K., \& Pudjawan, K. (2016). Pengembangan Video Pembelajaran Berbasis Kearifan Lokal Mata Pelajaran Bahasa Bali Untuk Siswa Kelas III. Journal Edutech Universitas Pendidikan Ganesha, 5(2). https://doi.org/0.23887/jeu.v4i2.7630.

Dewi, N. W. I. S., Suarsana, I. M., \& Suryawan, I. P. P. (2018). Pengaruh Model Pembelajaran Kolaboratif Berbantuan Masalah Autentik Terhadap Kemampuan Pemecahan Masalah Matematika. Jurnal Matematika, Sains, Dan Pembelajarannya Universitas Pendidikan Ganesha, 12(1), 26-41. https://doi.org/10.30998/jkpm.v2i2.2495.

Duane, B. T., \& Satre, M. E. (2014). Utilizing constructivism learning theory in collaborative testing as a creative strategy to promote essential nursing skills. Nurse Education Today, 34(1). https://doi.org/10.1016/j.nedt.2013.03.005.

Dwija Putri, I. G. A. M. A., Ulupui, I. G. K. ., \& Wirawati, N. G. P. (2017). Pengaruh Good Corporate Governance dan Budaya Tri Hita Karana Pada Kinerja Bank Perkreditan Rakyat. Jurnal Ilmiah Akuntansi Dan Bisnis, 17. https://doi.org/10.24843/jiab.2017.v12.i01.p03.

Fayakun, M., \& Joko, P. (2015). Efektivitas Pembelajaran Fisika Menggunakan Model Kontekstual (Ctl) Dengan Metodepredict, Observe, Explain Terhadap Kemampuan Berpikir Tingkat Tinggi. Jurnal Pendidikan Fisika Indonesia, 11(1), 49-58. https://doi.org/10.15294/jpfi.v11i1.4003.

Fitriani, S. (2019). Pendidikan Karakter Sebagai Upaya Menciptakan Akhlak Mulia Siswa Sekolah Dasar. ELSE (Elementary School Education Journal) : Jurnal Pendidikan Dan Pembelajaran Sekolah Dasar, 3(2), 229-238. https://doi.org/10.30651/else.v3i2.3011.

Gitriani, R., Aisah, S., Hendriana, H., \& Herdiman, I. (2018). Pengembangan Lembar Kerja Siswa Berbasis Pendekatan Kontekstual pada Materi Lingkaran Untuk Siswa SMP. Jurnal Review Pembelajaran Matematika, 3(1), 40-48. https://doi.org/10.15642/jrpm.2018.3.1.40-48.

Hamidah, F. N., \& Yanuarmawan, D. (2018). Pemanfaatan Internet Untuk Memvariasikan Sumber Belajar Bahasa Inggris dalam Meningkatkan Kinerja Guru. Jurnal ABDINUS : Jurnal Pengabdian Nusantara, 2(1). https://doi.org/10.29407/ja.v2i1.11790.

Harta, J., Rasuh, N. T., \& Seriang, A. (2020). Using HOTS-Based Chemistry National Exam Questions to Map the Analytical Abilities of Senior High School Students. Journal of Science Learning, 3(3), 143-148. https://doi.org/10.17509/jsl.v3i3.22387.

Havizul, H. (2020). Pengembangan Multimedia Interaktif Untuk Pembelajaran Ips Di Sekolah Dasar 
Menggunakan Model Ddd-E. Sosial Horizon: Jurnal Pendidikan Sosial, 6(2), 283. https://doi.org/10.31571/sosial.v6i2.1202.

Hernawati, F. (2016). Pengembangan Perangkat Pembelajaran Matematika Dengan Pendekatan Pmri Berorientasi Pada Kemampuan Representasi Matematis. Jurnal Riset Pendidikan Matematika, 3(1), 34. https://doi.org/10.21831/jrpm.v3i1.9685.

Hurriyah. (2017). Penerapan Model Kooperatif Tipe TAI ( Team Assisted Individualization ) Untuk Meningkatkan Pemahaman Konsep Dalam Pembelajaran Fisika Kelas X MIA. Natural Science Journal, 3(1), 328-335. https://doi.org/10.15548/nsc.v3i1.403.

Ichsan, I. Z., Sigit, D. V., Miarsyah, M., Ali, A., Arif, W. P., \& Prayitno, T. A. (2019). HOTS-AEP: Higher order thinking skills from elementary to master students in environmental learning. European Journal of Educational Research, 8(4), 935-942. https://doi.org/10.12973/eu-jer.8.4.935.

Indriyani, Dantes, \& Aryanto. (2017). Analisis Kebermanfaatan Website Sekolah Tinggi Pariwisata (Stipar) Triatma Jaya Menggunakan Metode Usability Testing. International Journal of Natural Science and Engineering, 1(2). https://doi.org/10.23887/ijnse.v1i2.12469.

Jampel, I. N., Fahrurrozi, Artawan, G., Widiana, I. W., Parmiti, D. P., \& Hellman, J. (2018). Studying natural science in elementary school using nos-oriented cooperative learning model with the NHT type. Jurnal Pendidikan IPA Indonesia, 7(2), 138-146. https://doi.org/10.15294/jpii.v7i2.9863.

Jampel, I. N., Fahrurrozi, Artawan, G., Widiana, I. W., Parmiti, D. P., \& Hellman, J. (2018). Studying natural science in elementary school using nos-oriented cooperative learning model with the NHT type. Jurnal Pendidikan IPA Indonesia, 7(2), 138-146. https://doi.org/10.15294/jpii.v7i2.9863.

Jessica, V., Halis, A., Ningsi, D. W., Virginia, G. F., \& Syahidah. (2017). Pemberantasan Buta Aksara untuk Peningkatan Kualitas Sumber Daya Manusia Masyarakat Sekitar Hutan Desa Manipi, Kecamatan Pana, Kabupaten Mamasa. Jurnal Ilmiah Pengabdian Kepada Masyarakat, 3(2). https://doi.org/10.29244/agrokreatif.3.2.136-142.

Kaban, R. H., Anzelina, D., Sinaga, R., \& Silaban, P. J. (2021). Pengaruh Model Pembelajaran PAKEM terhadap Hasil Belajar Siswa di Sekolah Dasar. Jurnal Basicedu, 5(1), 102-109. https://doi.org/10.31004/basicedu.v5i1.574.

Khayati, N. A., Muna, F., Oktaviani, E. D., Hidayatullah, \& Fauzan, A. (2020). Peranan Guru Dalam Pendidikan Inklusif Untuk Pencapaian Program Tujuan Pembangunan Berkelanjutan (SDG's). Komunikasi Pendidikan, 4(1). https://doi.org/10.32585/jkp.v4i1.440.

Kristiana, T. F., \& Radia, E. H. (2021). Meta Analisis Penerapan Model Problem Based Learning Dalam Meningkatkan Hasil Belajar IPA Siswa Sekolah Dasar. Jurnal Basicedu, 5(2), 818-826. https://doi.org/10.31004/basicedu.v5i2.828.

Kuantum, Cilacap, K., Ramadhan, G., Dwijananti, P., \& Wahyuni, S. (2018). Analisis Kemampuan Berpikir Tingkat Tinggi (High Order Thinking Skills) Menggunakan Instrumen Two Tier Multiple Choice Materi Konsep Dan Fenomena Kuantum Siswa Sma Di Kabupaten Cilacap. UPEJ Unnes Physics Education Journal, 7(3), 85-90. https://doi.org/10.15294/upej.v7i3.27682.

Lai, A., A. F., C., \& Lee, G. Y. (2019). An augmented reality-based learning approach to enhancing students' science reading performances from the perspective of the cognitive load theory. British Journal of Educational Technology, 50(1), 232-247. https://doi.org/10.1111/bjet.12716.

Leonard, N. C., \& Nwanekezi, A. U. (2018). Effects of Guided Inquiry and Task Hierarchy Analysis Model in Cooperative Learning Strategy on Chemistry Students' Performance in Imo State. European Scientific Journal, ESJ, 14(25), 54-62. https://doi.org/10.19044/esj.2018.v14n25p54.

Lian, B., Kristiawan, M., Ammelia, D., Primasari, G., Anggung, M., \& Prasetyo, M. (2020). Teachers' Model in Building Students' Character. Journal of Critical Reviews, 7(14), 927-932. https: //doi.org/10.31838/jcr.07.14.165.

Mawardi, Wardani, N. S., Hardini, A. T. A., \& Kristin, F. (2019). Model Desain Pembelajaran Tematik Terpadu Kontekstual Untuk Meningkatkan Kebermaknaan Belajar Siswa SD. Jurnal Pendidikan Dan Kebudayaan, 9(1). https://doi.org/10.24246/j.js.2019.v9.i1.p48-61.

Mulyani, S. (2020). Penerapan Metode Pembelajaran Problem Based Learning Guna Meningkatkan Hasil Belajar IPA Di Masa Pandemi Covid 19. Navigation Physics : Journal of Physics Education, 2(2), 8489. https://doi.org/10.30998/npjpe.v2i2.489.

Ndiung, S., \& Jediut, M. (2020). Pengembangan instrumen tes hasil belajar matematika peserta didik sekolah dasar berorientasi pada berpikir tingkat tinggi. Premiere Educandum : Jurnal Pendidikan Dasar Dan Pembelajaran, 10(1), 94. https://doi.org/10.25273/pe.v10i1.6274.

Nugrahanto, S., \& Zuchdi, D. (2019). Indonesia PISA Result and Impact on the Reading Learning Program in Indonesia. International Conference on Interdisciplinary Language, Literature and Education, 373377. https://doi.org/10.2991/icille-18.2019.77.

Nugrahanto, Septya, \& Zuchdi, D. (2019). Indonesia PISA Result and Impact on The Reading Learning 
Program in Indonesia. International Conference on Interdisciplinary Language, Literature and Education (ICILLE 2018), 297(0), 373-377. https://doi.org/10.2991/icille-18.2019.77.

Nurhidayati, E. (2017). Pedagogi Konstruktivisme dalam Praksis Pendidikan Indonesia. Indonesian Journal Of Educational Counseling, 1(1), 1-14. https://doi.org/10.30653/001.201711.2.

Pasaribu, A., \& Saparini. (2017). Pengembangan Bahan Ajar Berbasis Kontekstual untuk Meremidiasi Miskonsepsi pada Materi Gaya dan Hukum Newton. Jurnal Inovasi Dan Pembelajaran Fisika, 4(2), 36-47. https://doi.org/10.36706/jipf.v4i1.4264.

Prayito. (2011). Pengembangan Perangkat Pembelajaran Matematika Humanistik Berbasis Konstruktivisme Berbantuan E-Learning Materi Segitiga Kelas VII. AKSIOMA Journal of Mathematics Education, 2(2). https://doi.org/10.26877/aks.v2i2/Septembe.37.

Priantini, D. A. (2020). The Development Of Teaching Video Media Based On Tri Kaya Parisudha In Educational Psychology Courses. Journal of Education Technology, 4(4). https://doi.org/10.23887/jet.v4i4.29608.

Purwandari, A., \& Wahyuningtyas, D. T. (2017). Eksperimen Model Pembelajaran Teams Games Tournament (Tgt) Berbantuan Media Keranjang Biji-Bijian Terhadap Hasil Belajar Materi Perkalian Dan Pembagian Siswa Kelas Ii Sdn Saptorenggo 02. Jurnal Ilmiah Sekolah Dasar, 1(3), 163. https://doi.org/10.23887/jisd.v1i3.11717.

Putra, I. G. D., \& Sujana. (2020). Hasil belajar IPS menggunakan Kolaborasi Model Discovery Learning Berbasis Media Animasi. Journal of Educational Technology, 4, 103-109. https://doi.org/10.23887/jet.v4i2.25099.

Putrihapsari, R., \& Dimyati, D. (2021). Penanaman Sikap Sopan Santun dalam Budaya Jawa pada Anak Usia Dini. Jurnal Obsesi : Jurnal Pendidikan Anak Usia Dini, 5(2). https://doi.org/10.31004/obsesi.v5i2.1022.

Rusli, R., Rahman, A., \& Abdullah, H. (2020). Student perception data on online learning using heutagogy approach in the Faculty of Mathematics and Natural Sciences of Universitas Negeri Makassar, Indonesia. Data in Brief, 29, 105152. https://doi.org/10.1016/j.dib.2020.105152.

Selamet, N. W. (2017). Pengaruh Model Pembelajaran Numbered Head Together Berbasis Tri Kaya Parisudha Terhadap Hasil Belajar IPS Siswa Kelas IV". E- Journal PGSD Universitas Pendidikan Ganesha. MIMBAR PGSD Undiksha, 5(2), 1-11. https://doi.org/10.23887/jjpgsd.v5i2.10768.

Setiawan, Innatesari, D. K., Sabtiawan, W. B., \& Sudarmin, S. (2017). The development of local wisdom-based natural science module to improve science literation of students. Jurnal Pendidikan IPA Indonesia, 6(1), 49-54. https://doi.org/10.15294/jpii.v6i1.9595.

Somawati, A. V., \& Made, Y. A. D. N. (2019). Implementasi Ajaran Tri Kaya Parisudha Dalam Membangun Karakter Generasi Muda Hindu Di Era Digital. Jurnal Pasupati, 6(1). https: //doi.org/10.37428/pspt.v6i1.135.

Subali, B., Kumaidiac, Aminah, N. S., \& Sumintono, B. (2019). Student achievement based on the use of scientific method in the natural science subject in elementary school. Jurnal Pendidikan IPA Indonesia, 8(1), 39-51. https://doi.org/10.15294/jpii.v8i1.16010.

Suryani, N. K., Renda, N. T., \& Wibawa, I. M. C. (2019). Pengaruh Pendekatan Saintifik Berorientasi Tri Kaya Parisudha Terhadap Penguasaan Konsep Ipa Dan Keterampilan Proses Sains Siswa Kelas V Sd Di Gugus Vii Kecamatan Sukasada Kabupaten Buleleng Tahun Pelajaran 2018/2019. Journal of Education Technology. https://doi.org/10.23887/jet.v3i1.17962.

Suwannaphisit, S., Anusitviwat, C., Hongnaparak, T., \& Bvonpanttarananon, J. (2021). Expectations on online orthopedic course using constructivism theory: A cross-sectional study among medical students. Annals of Medicine and Surgery, 67. https://doi.org/10.1016/j.amsu.2021.102493.

Suwartini, S. (2017). Pendidikan Karakter dan Pembangunan Sumber Daya Manusia Keberlanjutan. Trihayu: Jurnal Pendidikan Ke SD An, 4(1), 220-234. https://doi.org/10.30738/trihayu.v4i1.2119.

Tompodung, T. C. G., Rushayati, S. B., \& Aidi, M. N. (2018). Efektivitas Program Adiwiyata Terhadap Perilaku Ramah Lingkungan Warga Sekolah Di Kota Depok. Journal of Natural Science and Integration, 8(2). https://doi.org/10.29244/jpsl.8.2.170-177.

Veronika, A. (2019). Implementasi Ajaran Tri Kaya Parisudha Dalam Membangun Karakter Generasi Muda Hindu Di Era Digital. Jurnal PASUPATI, 6(2). https: //doi.org/10.37428/pspt.v6i1.135.

Veronika, Ayu. (2019). Implementasi Ajaran Tri Kaya Parisudha Dalam Membangun Karakter Generasi Muda Hindu Di Era Digital. Jurnal PASUPATI. https://doi.org/10.37428/pspt.v6i1.135.

Widiasih, L. S. (2019). Pengaruh Model Pembelajaran SFAE Berbasis Tri Kaya Parisudha terhadap Hasil Belajar Matematika Siswa. Jurnal Ilmiah Sekolah Dasar, 3(2). https: //doi.org/10.23887/jisd.v3i2.17758.

Widodo, A. (2020). Nilai Budaya Ritual Perang Topat Sebagai Sumber Pembelajaran IPS Berbasis Kearifan Lokal di Sekolah Dasar. Gulawentah:Jurnal Studi Sosial, 5(1), 1. 
https://doi.org/10.25273/gulawentah.v5i1.6359.

Wijaya, A. P., Mahayukti, G. A., Gita, I. N., \& Parwati, N. N. (2019). Pengaruh strategi Relating, Experiencing, Applying, Cooperating, Transfering berorientasi kearifan lokal terhadap pemecahan masalah dan karakter. Pythagoras: Jurnal Pendidikan Matematika, 14(2), 178-187. https://doi.org/10.21831/pg.v14i2.25881.

Winataputra, U. S. (2016). Multikulturalisme-Bhinneka Tunggal lka Dalam Perspektif Pendidikan Kewarganegaraan Sebagai Wahana Pembangunan Karakter Bangsa Indonesia. Jurnal Pendidikan Dan Kebudayaan, 14(75). https://doi.org/10.24832/jpnk.v14i75.364.

Wulandari, F. E. (2016). Pengaruh Model Pembelajaran Berbasis Proyek untuk Melatihkan Keterampilan Proses Mahasiswa. PEDAGOGIA: Jurnal Pendidikan. https://doi.org/10.21070/pedagogia.v5i2.257.

Yamin, M., \& Syahrir, S. (2020). Pembangunan Pendidikan Merdeka Belajar (Telaah Metode Pembelajaran). Jurnal Ilmiah Mandala Education, 6(1), 126-136. https://doi.org/10.36312/jime.v6i1.1121.

Yuliati, L. (2013). Efektivitas Bahan Ajar Ipa Terpadu Terhadap Kemampuan Berpikir Tingkat Tinggi Siswa Smp. Jurnal Pendidikan Fisika Indonesia, 9(1), 53-57. https://doi.org/10.15294/jpfi.v9i1.2580.

Yuliati, Y., \& Lestari, I. (2019). Penerapan Model Creative Problem Solving untuk Meningkatkan Hasil Belajar Siswa Pada Pembelajaran Ilmu Pengetahuan Alam di Sekolah Dasar. Jurnal Cakrawala Pendas. https://doi.org/10.31949/jcp.v5i1.1200.

Yustina, \& Kapsin. (2017). The implementation of constructivism-based student worksheets within the theme 'the prevention of land and forest fire' in science education for seventh graders in Riau. Jurnal Pendidikan IPA Indonesia, 6(2), 298-305. https://doi.org/10.15294/jpii.v6i2.10573. 